\title{
Estimation of direct and maternal effects on body weight in Mehraban sheep using random regression models
}

\begin{abstract}
In the present study the growth data of Mehraban sheep were used to estimate direct and maternal additive genetic effects together with direct and maternal permanent environmental effects on body weight from birth to 270 days of age using random regression models. The fixed effects of the model were age of dam, type of birth and contemporary groups. Animal, dam, animal and maternal permanent environmental effects were considered as random effects. The models were fitted to the data using Legendre polynomials for age of lambs. Changes in residual (measurement error) variance with age were modeled by a variance function. Direct heritability estimates for the later ages with the least records tended to be overestimated, particularly heritability beyond 180 days. Maternal heritability estimates increased after birth to a maximum around 120 days of age and decreased thereafter. The results showed that covariance between weights of lambs for a considerable range of ages can be modelled properly using random regression.
\end{abstract}

Keywords: Mehraban sheep, body weight, random regression, variance function, heritability.

\section{Zusammenfassung}

Titel der Arbeit: Schätzung direkter und mütterlicher Effekte für das Körpergewicht bei Mehraban Schafen mittels Random Regressionsmodellen

Von der Geburt bis zum 270. Tag wurden Wachstumsdaten von 2746 Mehraban Schafen erfasst. Das Zufallsregressionsmodell wurde genutzt, um die direkten und mütterlichen additiv genetisch sowie direkten permanenten Umwelteffekte für das Körpergewicht zu schätzen. Als fixe Effekte im Modell galten: Alter der Mutter, Geburtstyp und zeitgleiche Gruppen. Als Zufallseffekte fanden die Tiereffekte, die Mutter und die permanenten Umwelteffekte der Probanden und der Mutter Berücksichtigung. Die Modellanpassung des Alters der Lämmer erfolgte mittels des Legendre Polynomials. Wegen des Altersanstiegs sich ergebende Änderungen der Restvarianzen (Messfehler) wurden durch eine Varianzfunktion modelliert. Die Heritabilitätsschätzwerte der mit geringerer Tierzahl vertretenen, älter als 180 Tage alten Schafe waren als überschätzt zu beurteilen. Die mütterlichen Heritabilitätsschätzwerte erhöhten sich nach der Geburt und erreichten mit etwa 120 Tagen den höchsten Wert und verringerten sich anschließend. Die Ergebnisse zeigten, dass die Zufallsregressionsmodelle die unterschiedlichen Kovarianzen des Körpergewichtes der Schafe bei unterschiedlichem Alter für den jeweiligen Zeitabschnitt gut modellieren.

$\underline{\text { Schlüsselwörter: Mehraban Schaf, Körpergewicht, Random Regression, Varianzfunktion, Heritabilität }}$

\section{Introduction}

Lamb and mutton are traditional sources of protein in Iran and the consumption levels are high in comparison with cattle and goats (YAZDI et al., 1997). The sheep population in Iran is mainly composed of fat-tailed carpet-wool native breeds. They are mostly adapted to the poor range conditions of the country. A high percentage of the sheep population is managed under a migratory system, utilizing the range as the major source of feed (FARID et al., 1977). The Mehraban breed is one of the common native breeds of Iran adapted to mountainous areas in western parts of the country. 
Due to the large population of this breed - about three million heads - there is an increasing interest to the genetic improving of this breed.

To formulate optimal breeding strategies to increase the efficiency of sheep production, knowledge of genetic parameters for these traits and also the genetic relationship between traits are needed (YAZDI et al., 1997). Traditionally, animals growth measured at various ages is analyzed with a multi-trait model (MTM) defining the phenotypic values at distinct ages as different traits (DOBEK et al., 2004; ATIL et al., 2005; KREJCOVA et al., 2007). One alternative to the genetic evaluation for growth by MTM is a random regression model (RRM) which was introduced by HENDERSON (1982). RRM facilitates the estimation of genetic parameters for traits that change continuously over the time (i.e. longitudinal data; KIRKPATRICK et al., 1990). Examples are body weight records taken at various points throughout an animal's life and test day milk production in dairy cows. MEYER (2004) reported that the accuracy of genetic evaluation of growth in beef cattle could be improved by replacing a MT model with RR models. This arose largely through more appropriate modeling of the genetic parameters due to avoidance of age preadjustment and possibility of taking into account of specific environmental effects on the time of recording. Decreasing of the generation interval because of prediction of breeding values for the growth curve as a whole, for any age (within the range in the data) using the genetic regression coefficients, increasing of precision of breeding values due to utilizing of a larger amount of data from each animal and possibility of calculating variances for every age and covariances between any pair of ages, are advantages of RR models.

The use of RRM in animal breeding is a recent innovation pioneered by researchers who worked on improving the prediction of genetic merit of dairy cattle (SWALVE, 1995; JAMROZIK et al., 1997; VAN DER WERF et al., 1998). Recently, RR models has become popular in analysis of beef cattle growth data (ALBUQUERQUE and MEYER, 2001; MEYER, 2001; MEYER, 2004; ARANGO et al., 2004; AZIZ et al., 2005; KREJCOVA et al., 2007). However, a few studies have been done on sheep growth data by this approach (LEWIS and BROTHERSTONE, 2002; FISCHER et al., 2004; SAFAEI et al., 2006).

Information on genetic parameters for body weight is sparse in Mehraban breed. Therefore the aim of the present investigation was to estimate genetic parameters due to direct and maternal effects for body weight from birth to 270 days of age using RRM. Development of a suitable model for the used data set was another objective of the present study.

\section{Material and Methods}

\section{Data}

Live weight records of 2746 Mehraban lambs collected between 1990 and 2005, originated from RAMPLANE database of animal breeding unit of Agriculture Organization of Hamadan Province in the west of Iran were used in this study. Usually, hand mating carried out once a year from September to the end of October. Lambing commenced in March. After lambing, the ewes and their lamb(s) were placed in separate pens and kept there for a few days. The lambs were weighed and ear tagged within $12 \mathrm{~h}$ of birth. The identities of newborn and of their parents, date of birth, sex, 
birth type and birth weight were recorded. All lambs were weaned around 90 days of age. Lambs were weighed at birth, then at weaning, and afterwards the lambs were weighed irregularly. Slaughter lambs are not kept until a certain age or weight, but are sold for different purposes at different ages.

Because there were few records after 270 days, these were eliminated to avoid computational problems due to small number of records. In addition, records with implausible dates or weights were also eliminated. This yielded a total of 9507 records on 2746 animals that were the progeny of 82 sires and 1235 dams. Mean weight of lambs in total period was $24.54 \pm 14.96 \mathrm{~kg}$.

\section{Statistical methods}

Fixed effects

Preliminarily least square analyses were conducted using the GLM procedure of SAS (2004) to identify nongenetic factors influencing lamb's weight. Factors considered in these models included type of birth (single or twin), dam age (in year-8 classes) and contemporary groups (year-season-sex) with 120 subclasses. All these fixed effects were significant $(\mathrm{P}<0.01)$ and were included in the fixed part of the models. The same fixed effects model was used for different random effect models, making restricted maximum likelihoods (REML) directly comparable.

\section{Random effects}

According to FISCHER et al. (2004), four sets of RR coefficients were fitted to the data. Direct and maternal genetic effects assumed to be proportionate to the numerator relationship matrix. Further analyses considering different orders of fit for the four random effects were carried out subsequently. The aim of doing so was to determine the minimum order of fit required for each random factor, and thus determining the most parsimonious model describing the data.

Model of analysis

The general model can be represented as follows:

$$
y_{i j=} F_{i j}+\sum_{m=0}^{3} \beta_{m} \phi_{m}\left(t_{i j}^{*}\right)+\sum_{m=0}^{k_{A-1}} \alpha_{i m} \phi_{m}\left(t_{i j}^{*}\right)+\sum_{m=0}^{k_{M-1}} \gamma_{i m} \phi_{m}\left(t_{i j}^{*}\right)+\sum_{m=0}^{k_{C-1}} \delta_{i m} \phi_{m}\left(t_{i j}^{*}\right)+\sum_{m=0}^{k_{Q-1}} \rho_{i m} \phi_{m}\left(t_{i j}^{*}\right)+\varepsilon_{i j}
$$

where: $y_{i j}$ is the $j^{\text {th }}$ record from $i^{\text {th }}$ animal; $F_{i j}$ is a set of fixed effects; $\beta_{m}$ are the fixed regression coefficients for modeling the population mean; $\phi_{m}\left(t_{i j}^{*}\right)$ is the $m^{\text {th }}$ Legendre polynomial of age; $t_{i j}^{*}$ is the standardized $(-1<\mathrm{t}<1)$ age at recording; $\alpha_{i m}, \gamma_{i m}, \delta_{i m}$ and $\rho_{i m}$ are the random regression coefficients for direct genetic, maternal genetic, and direct and maternal permanent environmental effects, respectively; $k_{A-1}, k_{M-1}, k_{C-1}$ and $k_{Q-1}$ are the corresponding order of (polynomial) fit for each effect and $\varepsilon_{i j}$ denotes the residual (measurement error) effect.

In order to investigate the maternal effects, two models were used. The first model included only maternal permanent environmental effect with direct effects and the second included both maternal genetic and maternal permanent environmental effects in addition to direct effects. Differences in likelihoods for these models were used to 
evaluate the importance of maternal genetic effects and the ability to separate maternal genetic and permanent environmental components.

Residual effects $(\varepsilon)$ were considered independently distributed, with variances modeled by a quadratic or cubic variance function (VF) assuming a log-linear model as described by MEYER (2001):

$$
\sigma_{j}^{2}=\sigma_{0} \exp \left\{1+\sum_{r=1}^{v-1} b_{r}\left(t_{i j}^{*}\right)^{r}\right\}
$$

where: $\sigma_{j}^{2}$ is the variance at the $j^{\text {th }}$ age, $\sigma_{0}^{2}$ is the error variance at the mean age, and $b_{r}$ and $v$ are the coefficients and the number of parameters of the $\mathrm{VF}$, respectively. When VF is applied, it allows an exponential increase in variance with time to be modeled parsimoniously by a simple linear regression. Moreover, it does not require any constraints on the coefficients of the polynomial regression to be imposed MEYER (2001).

\section{Covariance functions}

Parameters estimated in RR analyses were the $\mathrm{K}$ matrices containing variances and covariances between RR coefficients. If $\Phi$ denote a matrix that containing Legendre polynomials pertaining to a set of specific ages, then $\Phi$ could be obtained as follows:

$$
\Phi=M \Lambda
$$

where: $M$ is a matrix containing the polynomials of the corresponding standardized ages and $\Lambda$ is a matrix containing the coefficients of the Legendre polynomials of a given order. The elements of the additive genetic covariance matrix (G) can be expressed as follows:

$$
G=\Phi K \Phi^{\prime}=M\left(\Lambda K \Lambda^{\prime}\right) M^{\prime}
$$

where: $K$ is a matrix of coefficients that define the covariance function. Covariance matrices for the other random effects can be expressed in similar fashion.

All estimates were obtained by REML using the DXMRR program (MEYER, 1998) which uses the average information (AI) algorithm to locate the maximum of the likelihood. Models with different orders of fit and random effects were compared by log-likelihood ratio test (LRT) and Akaike's information criterion (AIC) (WOLFINGER, 1996).

\section{Results and Discussion}

Number of records and mean weights for various ages are shown in Figure 1. Body weight has an increasing pattern with age from birth to 270 days of age, with a decrease in growth rate after weaning.

In total, seven models were fitted to the data and a description of each with the corresponding Log L and AIC values are given in Table 1. Increasing the order of fit for direct and maternal permanent environmental effects from 3 to 4 (Model 6) improved the fit to the data as indicated by an increase in $\log L(p \leq 0.01)$ over than other models. MEYER (2001) reported similar findings. A significant increase $(\mathrm{p} \leq 0.01)$ in accuracy, as indicated by Log L value, occurred by substitution quadratic with cubic VF, which is consistent with ALBUQUERQUE and MEYER (2001), and substantially arises from more flexibility of higher order polynomials than lower order 
polynomials (MEYER, 2005). A set of attempts to separate maternal genetic from maternal permanent environmental variances, Model 5 and Model 6, was conducted. Including maternal genetic effect to the model of analysis, significantly $(p \leq 0.01)$ increases the Log L, which is in accordance with ALBUQUERQUE and MEYER (2001) and MEYER (2001), indicated the importance of maternal genetic effect on lamb's weight.

Table 1

Order of fit for direct genetic $\left(k_{A}\right)$ maternal genetic $\left(k_{M}\right)$, direct permanent environmental $\left(k_{C}\right)$ and maternal permanent environmental $\left(k_{Q}\right)$ effects (Anpassungsordnung für direkte genetische $\left[k_{A}\right]$, mütterliche genetische $\left[k_{M}\right]$, direkte permanente umweltbedingte $\left[k_{C}\right]$ und mütterliche permanente umweltbedingte $\left[k_{Q}\right]$ Effekte)

\begin{tabular}{ccccccccc}
\hline Model & $k_{A}$ & $k_{M}$ & $k_{C}$ & $k_{Q}$ & $\mathrm{v}^{\mathrm{a}}$ & $\mathrm{Np}^{\mathrm{b}}$ & $\operatorname{Log~L}^{\mathrm{c}}$ & $\mathrm{AIC}^{\mathrm{d}}$ \\
\hline 1 & 3 & 3 & 3 & 3 & 3 & 27 & 176 & 268 \\
2 & 3 & 4 & 3 & 4 & 3 & 36 & 121 & 378 \\
3 & 4 & 4 & 3 & 3 & 3 & 36 & 170 & 280 \\
4 & 3 & 3 & 4 & 4 & 2 & 35 & 224 & 173 \\
5 & 3 & 0 & 4 & 4 & 3 & 30 & 36 & 549 \\
6 & 3 & 3 & 4 & 4 & 3 & 36 & $311^{* *}$ & 0 \\
7 & 4 & 4 & 4 & 4 & 3 & 44 & 0 & 623 \\
\hline
\end{tabular}

$\mathrm{a}=$ Order of fit for variance function, $\mathrm{b}=$ Number of parameters, $\mathrm{c}=$ Log likelihood function (showed as a deviation from the lowest value), $\mathrm{d}=$ Akaike's information criterion (showed as a deviation from the lowest value), ${ }^{* *}=\mathrm{p} \leq 0.01$

Both LRT and AIC suggested that a model with $\mathrm{k}=3,3,4,4$ and $\mathrm{v}=4$, with a total of 36 parameters (Model 6) was adequate to model the variances in the data.

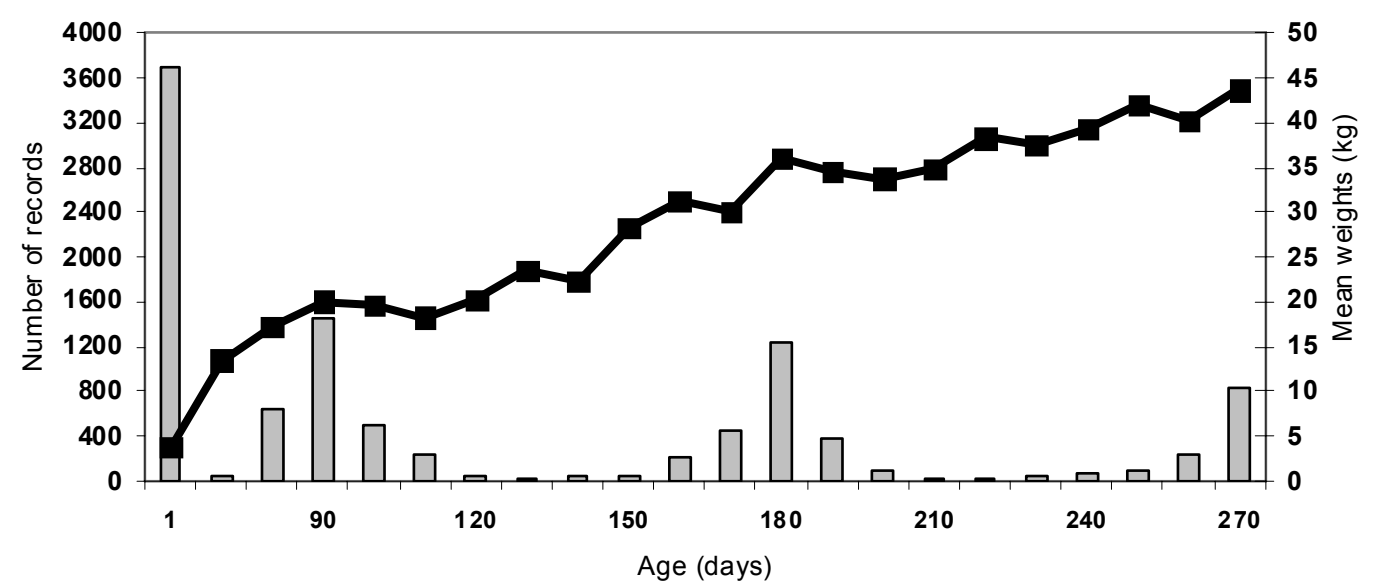

Fig. 1: Number of records and mean weights for various ages of Mehraban lambs (Anzahl der Aufzeichnungen und Mittelwert des Körpergewichts von Mehrabanschafen bei unterschiedlichem Alter)

\section{Random regression coefficients}

Estimates of covariance matrices between RR coefficients and corresponding correlations for Model $6(3,3,4,4)$ are listed in Table 2.

In all cases intercept of the polynomial regression explained the highest proportion of variation, and there were positive correlations between the linear and intercept coefficients for all effects with the exception of maternal permanent environmental effect. FISCHER et al. (2004) reported similar results for the decomposition of covariance functions. In addition, correlations between the intercept and quadratic coefficients were negative for A, C and Q and positive for M. Strong correlations between random regression coefficients caused one eigenvalue of the estimated covariance matrices to be essentially zero. A large eigenvalue represents considerable genetic variation for pattern of and changes in the growth curve that can be improved 
Table 2

Estimated coefficient matrices of the covariance functions and the corresponding eigenvalues of the covariance matrices and the correlations (above diagonal) between random regression coefficients for direct additive genetic (A), maternal additive genetic (M), direct permanent environmental (C) and maternal permanent environmental (Q) effects

(Matrizen der geschätzten Koeffizienten von Kovarianz-Funktionen und mit den Kovarianz-Matrizen entsprechende Eigenwerte und Korrelationen [über Diagonale] unter den Zufallsregressionskoeffizienten für die direkten additiven genetischen Effekte [A], die mütterlichen additiven genetischen Effekte [M], die direkten permanenten umweltbedingten Effekte [C] und mütterlichen permanenten umweltbedingten Effekte [Q])

\begin{tabular}{|c|c|c|c|c|}
\hline $0^{\mathrm{a}}$ & $1^{b}$ & $2^{\mathrm{c}}$ & $3^{d}$ & Eigenvalue \\
\hline \multicolumn{5}{|l|}{$\mathrm{A}$} \\
\hline 8.600 & 0.987 & -0.274 & & 9.507 \\
\hline 2.963 & 1.048 & -0.042 & & 0.451 \\
\hline-0.406 & -0.022 & 0.254 & & 0.002 \\
\hline \multicolumn{5}{|l|}{ M } \\
\hline 1.553 & 0.935 & 0.632 & & 1.855 \\
\hline 0.649 & 0.311 & -0.237 & & 0.033 \\
\hline 0.286 & -0.048 & 0.132 & & 0.005 \\
\hline \multicolumn{5}{|l|}{$\mathrm{C}$} \\
\hline 1.012 & 0.899 & -0.950 & 0.436 & 1.321 \\
\hline 0.275 & 0.092 & -0.888 & 0.125 & 0.023 \\
\hline-0.171 & -0.048 & 0.032 & -0.412 & 0.000 \\
\hline 0.024 & 0.002 & -0.004 & 0.003 & 0.003 \\
\hline \multicolumn{5}{|l|}{ Q } \\
\hline 1.723 & -0.803 & -0.988 & 0.177 & 2.340 \\
\hline-0.264 & 0.062 & 0.853 & -0.176 & 0.012 \\
\hline-0.991 & 0.163 & 0.585 & -0.009 & 0.000 \\
\hline 0.043 & -0.008 & -0.001 & 0.032 & 0.054 \\
\hline
\end{tabular}

$\mathrm{a}=$ Intercept, $\mathrm{b}=$ Linear, $\mathrm{c}=$ Quadratic, $\mathrm{d}=$ Cubic

by selection, whereas small or zero eigenvalue indicates that the change will be slow. The first eigenvalue of the $\mathrm{K}$ matrix for $\mathrm{A}, \mathrm{M}, \mathrm{C}$ and $\mathrm{Q}$ was the largest throughout, indicating that a large proportion of the total variance $(95-98 \%)$ can be explained by the first eigenfunction of each CF. FISCHER et al. (2004) working with Poll Dorset sheep, reported that $89-94 \%$ of total variation can be explained by the first eigenfunction of each $\mathrm{CF}$, that is in agreement with our findings.

Eigenfunctions that estimated from the eigenvectors of the genetic covariance matrix provide an insight into the effects of selection across the growth trajectory (KIRKPATRICK et al., 1990). They are calculated from the covariance matrix of the random animal effects. To each eigenfunction there is a specific eigenvalue and eigenvector. In addition, a small portion of variation ( $5 \%$ ) can be explained by second and third eigenvalues from direct additive genetic covariance function, suggesting that there is some scope to alter growth patterns genetically (FISCHER et al., 2004).

\section{Estimates of variance components}

Figure 2 gives the estimates of variance components for Model $6(3,3,4,4)$ for each random component. Direct additive genetic variance increased steadily over the trajectory. LEWIS and BROTHERSTONE (2002), FISCHER et al. (2004) and SAFAEI et al. (2006) reported a similar pattern of variation for direct additive genetic variance. Just the same as direct additive genetic variance, direct permanent environmental variance increased with age and reached to a peak at 240 days of age and remained relatively constant thereafter. Maternal additive genetic variance increased after birth to a peak around 150 days and decreased thereafter. Likewise, maternal permanent environmental variance increased after birth to a peak around 
weaning age and decreased near to zero at the end of the trajectory. SAFAEI et al. (2006) reported that maternal variances tended to be higher at younger ages, and declines with age, particularly beyond post-weaning ages ( $>120$ days).
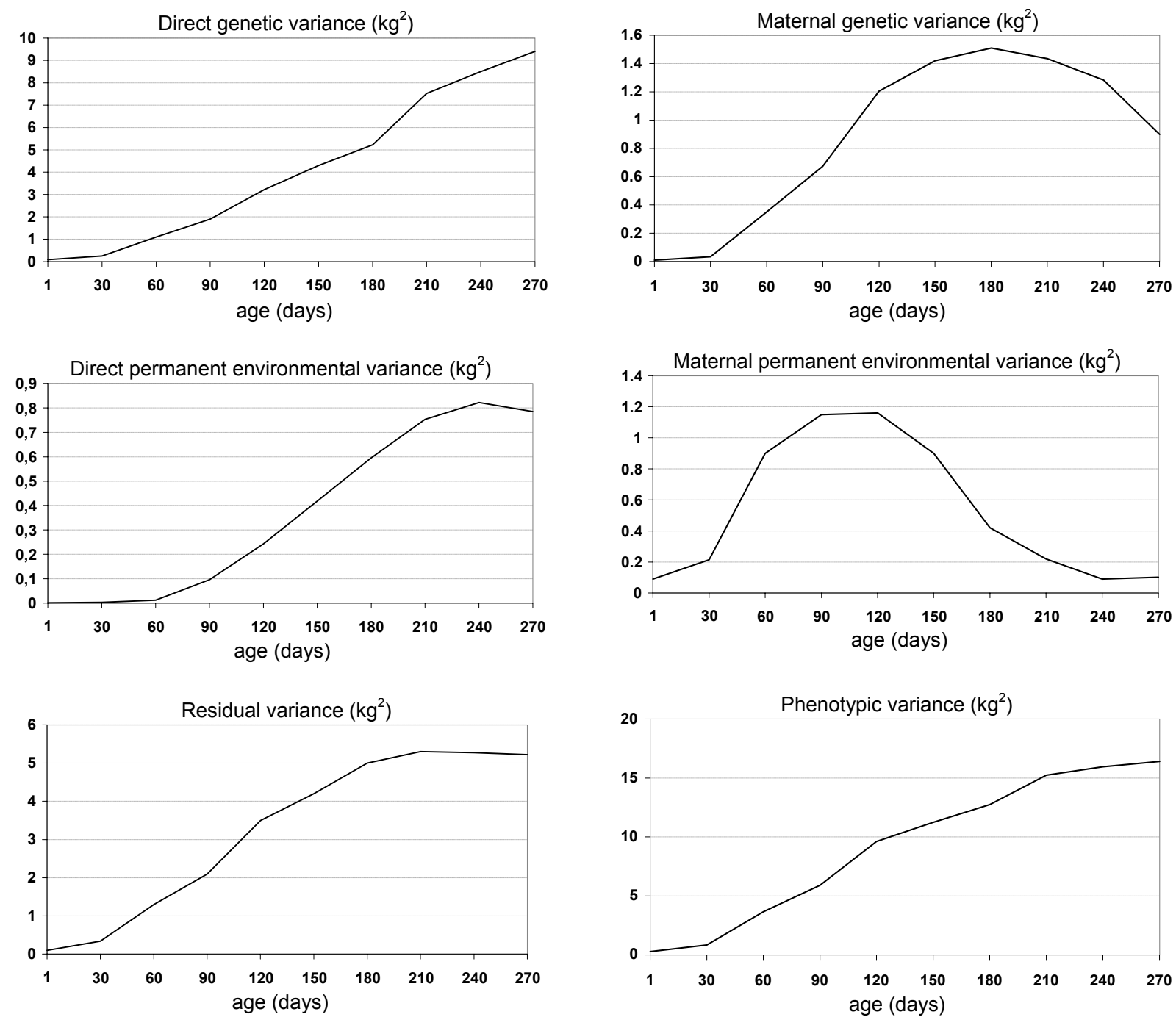

Fig. 2: Estimates of direct additive genetic, maternal additive genetic, direct permanent environmental, maternal permanent environmental, residual and phenotypic variances

(Schätzungen der direkten additiven genetischen Varianzen, der mütterlichen additiven genetischen Varianzen, der direkten permanenten umweltbedingten Varianzen, der mütterlichen permanenten umweltbedingten Varianzen und Messfehler sowie des aus der Zufallsregressionsanalyse erzeugten Phänotyps)

\section{Heritability}

Estimates of direct and maternal heritability are given in Figure 3. Direct heritability estimates for lamb's body weight up to 180 days of age was within the range of those presented in the literature (SNYMAN et al., 1995; FOGARTY, 1995; YAZDI et al., 1997; SAFAEI et al., 2006; MIRAEI-ASHTIANI et al., 2007). Direct heritability has increasing trend from earlier ages to later ages, which is in agreement with other reports (SNYMAN et al., 1995; YAZDI et al., 1997; FISCHER et al., 2004; SAFAEI et al., 2006). It must likely caused by two reasons, increasing in the expression of genes with direct additive effects on body development and decrease in variances due to maternal effects in later ages, which caused the larger fraction of phenotypic variance to be direct additive genetic variance and consequently larger direct heritability estimates for later ages. 

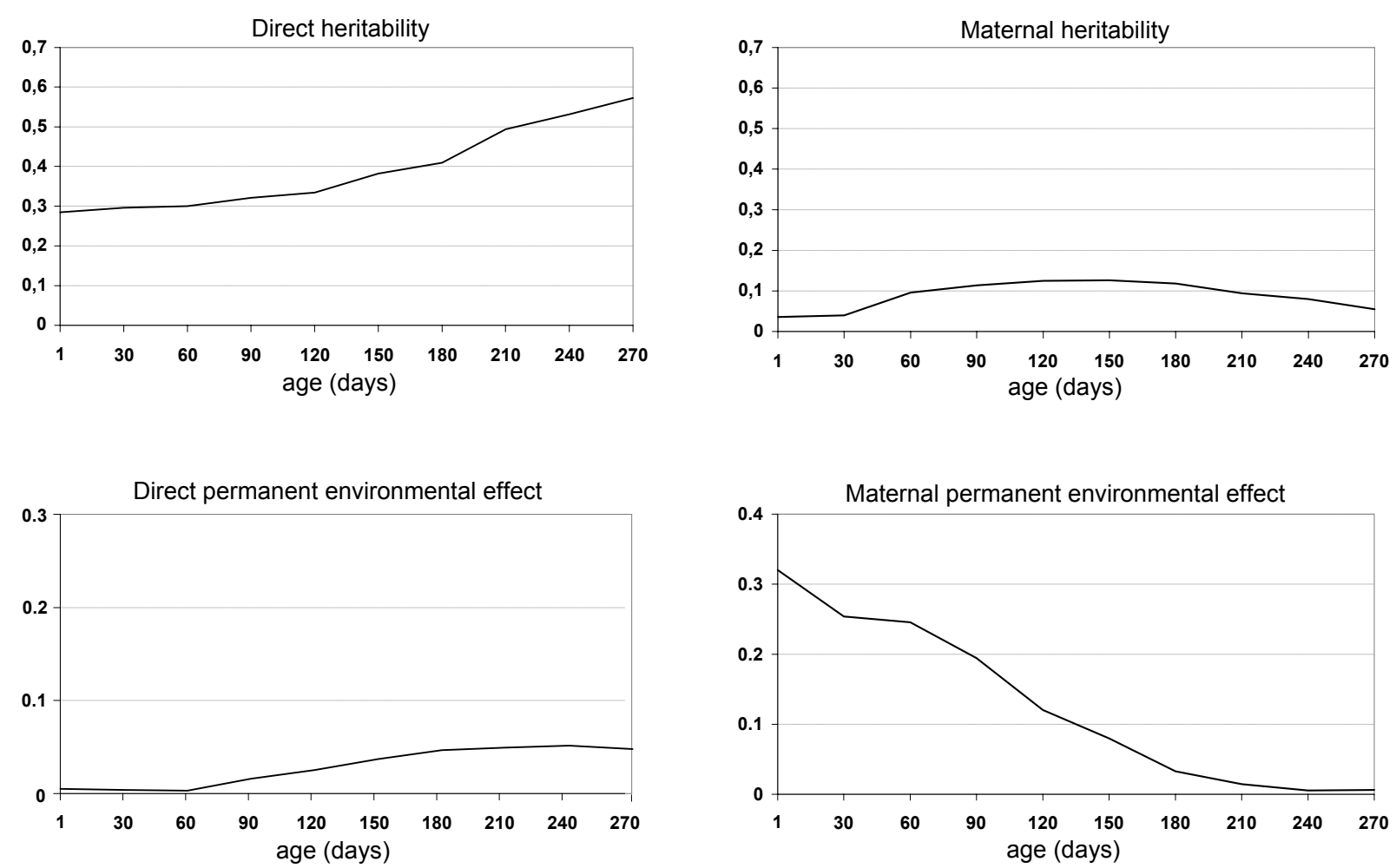

Fig. 3: Estimates of direct and maternal heritability and direct and maternal permanent environmental effects (Einschätzungen der direkten und mütterlichen Heritabilität und aus der Zufallsregressionsanalyse erzeugte direkte bzw. mütterliche permanente umweltbedingte Effekte)

Direct heritability appeared to increase sharply toward the end of the trajectory in particular beyond 180 days of age, and was larger than those presented in the literature (FOGARTY, 1995; YAZDI et al., 1997; FISCHER et al., 2004; MIRAEI-ASHTIANI et al., 2007). Similar behaviour of covariance function estimates for ages where the least data is present at the end of the trajectory has been reported by MEYER (2002) and FISCHER et al. (2004) and when the data are evenly spread across the trajectory (FISCHER and VAN DER WERF, 2002; NOBRE et al., 2003). This has been especially prevalent at the highest ages with least records, for data sets with many more records at earlier than later ages, and for analyses where substantial proportions of animals had fewer records than the order of polynomials fitted. This remains an unresolved problem for RR models based on Legendre polynomials. Substantially, this problem arises from sensitivity of Legendre polynomials to data structure and named "end effect of polynomials" or "Runge's phenomenon" (MEYER, 2005) which tends to be more outstanding at the extremities (VERBYLA et al., 1999). Moreover, the error of polynomial approximation of a curve increased with the order of polynomial fit. Higher order polynomials are flexible and have been found to be capable of modeling changes in means and variances along a continuous scale. However, such polynomials often put a high emphasis on observations at the extremes, and are notoriously problematic for high orders of fit (MEYER, 2005). Therefore polynomials regression may not be most appropriate functions.

ARANGO et al. (2004) reported inadequacy of RRM to model genetic variability at later ages. NOBRE et al. (2003) reported that parameter estimates obtained by fitting polynomials could be affected by sparse data and extremes of trajectory. In addition 
the large number of parameters to be estimated is another limitation of RRM based on Legendre polynomials. Other scientists successfully applied RRM based on Spline functions (VERBYLA et al., 1999; MEYER, 2005) and parametric covariance structures such as structured ante dependence (SAD) models (NUNEZ-ANTON and ZIMMERMAN, 2000) to longitudinal data to removing these problems.

Maternal heritability increased from birth to 120 days and then decreased gradually until 270 days of age, which was consistent with studies in sheep (SNYMAN et al., 1995) and beef cattle (AZIZ et al., 2005). ALBUQUERQUE and MEYER (2001) found that maternal heritability maximized near weaning, which is very important in selection based on maternal ability. According to current study, maternal genetic influence on all weights in comparison with direct genetic effect was low. This was presumably due to the poor quality of the pasture, preventing the ewe's genetic ability to provide enough milk for her lamb(s). Thus, the lack of enough milk production could be masking the expression of maternal ability of the ewes.

\section{Permanent environmental effects}

The proportion of direct permanent environmental variance and maternal permanent environmental variance to phenotypic variance are shown in Figure 3. Direct permanent environmentaleffect was low at all ages $(<0.10)$ and shows a gradual increase after 60 days of age until approximately 180 days of age, where it plateaus. Maternal permanent environmental effect was high at birth, when direct effects had least importance, but decreased sharply after weaning. Most studies reported the decrease of maternal permanent environmental effect as time lapses post weaning (ALBUQUERQUE and MEYER, 2001; SAFAEI et al., 2006). MARIA et al. (1993) reported that differences of maternal permanent environmental effect between pre- and post-weaning ages could be that suckling lambs are still dependent on mothers, whereas weaned lambs depend on themselves. Furthermore, the influences of the nonpermanent environmental factors become more important after weaning.

Overall, maternal effects are noticeable in early stages of Mehraban lamb's life. A number of reports indicate strong maternal effects on early growth traits in sheep (SZWACZKOWSKI et al., 2006; MIRAEI-ASHTIANI et al., 2007) and beef cattle (MEYER, 2001; ATIL et al., 2005). DOBEK et al. (2004) concluded that where maternal effects were not taken into consideration, is cause to upward bias in estimates of direct heritability. A model that contains both direct and maternal effects should provide more precise predictive ability of future progeny performance than a model that contains only direct genetic effects (SZWACZKOWSKI et al., 2006). However, the tendency of decreasing maternal effects on lamb's weight from early ages to 270 days of age shows that ability of Mehraban ewes to increase the body weight of lambs at pre-weaning ages seems to be the only meaningful maternal trait to include in the selection criterion, in any.

\section{Correlations}

Table 3 shows the direct genetic and phenotypic correlations between the weights at selected ages. The pattern of direct genetic and phenotypic correlations were similar, the correlations decreased as the age distance between weights increased. In particular the direct genetic correlation between adjacent days approaches unity. Direct genetic correlation between birth weight and other weights were lower than the corresponding 
values observed between weights at adjacent ages, suggesting that birth weight is not under the same genetic control as weights at other ages. LEWIS and BROTHERSTONE (2002) and AZIZ et al. (2005) reported similar results; correlations of birth weight with weights taken at other ages were lower than those between weights measured at adjacent ages. In such a situation, body weight at later ages can not be well predicted from body weight at earlier ages. However, direct genetic correlations were all positive; suggesting that selection for body weight at an earlier age would have a positive effect on body weight at later ages.

Maternal genetic correlation (not shown) displayed a similar trend to the direct genetic and phenotypic correlations (i.e. estimates decreased with increasing time between measurements). In addition, the maternal genetic correlations between BW and days over 180 were lower than 0.3 , suggesting that very little genetic relationship exist between maternal genetic control of fetal growth and milk production. Maternal genetic correlations between weights from 180 to 270 days of age were higher than 0.6 , indicating that maternal effects at later ages are primarily governed by the same genes.

Table 3

Direct genetic (above diagonal) and phenotypic (below diagonal) correlations between weights at selected ages (in days) (Direkte genetische [über Diagonale] und phänotypische [unter Diagonale] Korrelationen des Körpergewichts bei ausgewähltem Alter [in Tagen])

\begin{tabular}{rcccccccccc}
\hline Age & 1 & 30 & 60 & 90 & 120 & 150 & 180 & 210 & 240 & 270 \\
\hline 1 & 1.00 & 0.59 & 0.54 & 0.52 & 0.48 & 0.47 & 0.47 & 0.43 & 0.47 & 0.42 \\
30 & 0.67 & 1.00 & 0.82 & 0.75 & 0.74 & 0.65 & 0.62 & 0.61 & 0.56 & 0.55 \\
60 & 0.61 & 0.83 & 1.00 & 0.92 & 0.90 & 0.87 & 0.84 & 0.76 & 0.72 & 0.66 \\
90 & 0.51 & 0.72 & 0.89 & 1.00 & 0.99 & 0.95 & 0.86 & 0.81 & 0.69 & 0.68 \\
120 & 0.55 & 0.65 & 0.83 & 0.91 & 1.00 & 0.98 & 0.93 & 0.89 & 0.77 & 0.70 \\
150 & 0.51 & 0.61 & 0.81 & 0.86 & 0.85 & 1.00 & 0.87 & 0.86 & 0.77 & 0.73 \\
180 & 0.52 & 0.57 & 0.77 & 0.78 & 0.78 & 0.77 & 1.00 & 0.98 & 0.95 & 0.89 \\
210 & 0.43 & 0.56 & 0.75 & 0.75 & 0.75 & 0.77 & 0.86 & 1.00 & 0.92 & 0.91 \\
240 & 0.38 & 0.52 & 0.61 & 0.66 & 0.72 & 0.74 & 0.79 & 0.79 & 1.00 & 0.97 \\
270 & 0.34 & 0.48 & 0.53 & 0.57 & 0.61 & 0.66 & 0.68 & 0.71 & 0.73 & 1.00 \\
\hline
\end{tabular}

The results of current study have indicated that birth weight is a different trait from body weights at older ages and hence to some extent is under different genetic control. The moderate heritability estimates for body weight in current study indicated that substantial improvement could be achieved by selection. In addition, direct genetic correlations among body weights of Mehraban lambs for all ages were positive; indicating that selection for weaning weight would also increase birth weight and other weights. Although direct heritability for the later ages with the least records tended to be overestimated, but for practical selection purposes, such estimates are not an important constraint, because selection using weight at such later ages usually would not be practiced.

Acknowledgements

Hosein Mohammadi is gratefully acknowledged for his contribution toward the supply and preparation of the data. We thank Mostafa Afshari for help in revising and correcting the English of this manuscript. 


\section{References}

ALBUQUERQUE, L.G.; MEYER, K.:

Estimates of covariance functions for growth from birth to 630 days of age in Nelore cattle. J. Anim. Sci. 79 (2001), 2776-2789

ARANGO, J.R.; CUNDIFF, L.V.; VAN VLECK.; L.D.:

Covariance functions and random regression models for cow weight in beef cattle. J. Anim. Sci. 82 (2004), 54-67

ATIL, H.; SALAH KHATTAB, A.; BADAWY, L.:

Genetic parameter of birth and weaning weights for Friesian calves by using an animal model. Arch. Tierz. 48 (2005), 261-269

AZIZ, M. A.; NISHIDA, S.; SUZUKI, K.; NISHIDA, A.:

Estimation of direct and maternal genetic and permanent environmental effects for weights from birth to 356 days of age in a herd of Japanese Black cattle using random regression. J. Anim. Sci. 83 (2005), $519-530$

DOBEK, A.; WOJTOWSKI, J.; SZWACZKOWSKI, T.; MOLINSKI, K.; GUT, A.:

Genetic variability for birth and fourth week weights in sheep. Arch. Tierz. 47 (2004) Special Issue, 6472

FARID. A.; MAKARECHIAN, M.; SEFIDBAKHT, N.:

Crossbreeding of Iranian fat-tailed sheep: lamb performance of karakul, mehraban and naeini breeds. J. Anim. Sci. 44 (1977), 542-548

FISCHER, T.M.; VAN DER WERF, J.H.J.; BANKS, R. G.; BALL, A.J.: Description of lamb growth using random regression on field data. Livest. Prod. Sci. 83 (2004), 175-185

FISCHER, T.M.; VAN DER WERF, J.H.J.:

Effect of data structure on the estimation of genetic parameters using random regression. Proc. $7^{\text {th }}$ World Conger. Genet. Appl. Livest. Proc. CD-ROM Communication, Montpellier, France 17 (2002) 8

FOGARTY, N.M.:

Genetic parameters for live weight, fat and muscle measurements, wool production and reproduction in sheep: a review. Anim. Breed. Abstr. 63 (1995), 101-143

HENDERSON, C.R. JR.:

Analysis of covariance in the mixed model: higher level, nonhomogeneous, and random regressions. Biometrics 38 (1982), 623-640

JAMROZIK, J.; SCHAEFFER L.R.; DEKKERS, J.C.M.:

Genetic evaluation of dairy cattle using test day yields and random regression model. J. Dairy. Sci. 80 (1997), 1217-226

KREJCOVA, H.; MIELENZ, N.; PRIBYL, J.; SCHÜLER, L.:

Estimation of genetic parameters for daily gains of bulls with multi-trait and random regression models. Arch. Tierz. 50 (2007), 37-46

KIRKPATRICK, M.; LOFSVOLD, D.; BULMER, M.:

Analysis of the inheritance, selection and evolution of growth trajectories. Genetics. 124 (1990), 979-993

LEWIS, R.M.; BROTHERSTONE, S.:

A genetic evaluation of growth in sheep using random regression techniques. Anim. Sci. 74 (2002), 63-70

MARIA, G.A.; BOLDMAN, K.G.; VAN VLECK, L.D.:

Estimates of variances due to direct and maternal effects for growth traits of Romanov sheep. J. Anim. Sci. 71 (1993), 845-849

MEYER, K.:

"DXMRR" - a program to estimate covariance functions for longitudinal data by restricted maximum likelihood, in: Proc. $6^{\text {th }}$ World Conger. Genet. Appl. Livest. Proc., Armidale. NSW, Australia 27 (1998), $465-466$

MEYER, K.:

Estimates of direct and maternal covariance functions for growth of Australian beef calves from birth to weaning. Genet. Sel. Evol. 33 (2001), 487-514

MEYER, K.:

Estimates of covariance functions for growth of Australian beef cattle from a large set of field data. Proc. $7^{\text {th }}$ World Conger. Genet. Appl. Livest. Proc. CD-ROM Communication 1. Montpellier, France 11 (2002), 1

MEYER, K.:

Scope for a random regression model in genetic evaluation of beef cattle for growth. Livest. Prod. Sci. 86 (2004), 68-83

MEYER, K.;

Random regression analyses using B-splines to model growth of Australian Angus cattle. Genet. Sel.

Evol. 37 (2005), 473-500. 
MIRAEI-ASHTIANI, S.R.; SEYEDALIAN, S.A.R.; MORADI SHAHRBABAK, M.:

Variance components and heritabilities for body weight traits in Sangsari sheep, using univariate and multivariate animal models. Small. Rum. Res. 67 (2007), 271-278

NOBRE, P.R.C.; MISZTAL, I.; TSURUTA, S.; BERTRAND, J.K.; SILVA, L.O.C.; LOPES, P.S.:

Analyses of growth curves of Nelore cattle by multiple-trait and random regression models. J. Anim. Sci. 81 (2003), 918-926

NUNEZ-ANTON, V.; ZIMMERMAN, D. L.:

Modeling non-stationary longitudinal data. Biometrics 56 (2000), 699-705

SAS:

SAS/STAT Software Release 9.0., Cary, NC, USA (2004)

SAFAEI, M.; ESKANDARINASAB, M.; SHEARBAFTOOSY, A.:

Estimates of genetic parameters for growth traits in Baluchi sheep using random regression models. Agri. Sci. Tech. 20 (2006), 93-102 [in Persian with English abstract]

SZWACZKOWSKI, T.; WOJTOWSKI, J.; STANISLAWSKA, E.; GUT, A.:

Estimates of maternal genetic and permanent environmental effects in sheep. Arch. Tierz. 49 (2006) Special Issue, 186-192

SNYMAN, M.A.; ERASMUS, G.J.; VAN WYK, J.B.; OLIVIER, J.J.:

Direct and maternal (co) variance components and heritability estimates for body weight at different ages and fleece traits in Afrino sheep. Livest. Prod. Sci. 44 (1995), 229-235

SWALVE, H.H.:

Test day models in the analysis of dairy production data - a review. Arch. Tierz. 38 (1995), 591-612

VAN DER WERF, J.H.; GODDARD, M.E.; MEYER, K.:

The use of covariance function based on test day records. J. Dairy. Sci. 81 (1998), 3300-3308

VERBYLA, A.P.; CULLIS, B.R.; KENWARD, M.G.; WELHAM, S.J.:

The analysis of designed experiments and longitudinal data using smoothing splines. J. Roy. Stat. Soc.

Ser. C Appl. Stat. 48 (1999), 269-300

WOLFINGER, R.D.:

Covariance structure in general mixed models. Commun. Stat. 22B (1996), 1079-1106

YAZDI, M.H.; ENGSTROM, G.; NASHOLM, A.; JOHANSSON, K.; JORJANI, H.; LILJEDAHL, L.E.:

Genetic parameters for lamb weight at different ages and wool production in Baluchi sheep. Anim. Sci. 65 (1997), 247-255

Received: 2007-07-07

Accepted: 2008-03-23

\author{
Authors: \\ FARHAD GHAFOURI KESBI* \\ Dr. MORADPASHA ESKANDARINASAB \\ Dr. MOHAMMAD HOSEIN SHAHIR \\ Department of Animal Science \\ Faculty of Agriculture \\ Zanjan University \\ Zanjan \\ Iran \\ *Corresponding author \\ email: f_ghafouri@znu.ac.ir
}

